\title{
Direct and Indirect Effects of the Highseas Fisheries on the Marine Mammal Populations in the Northern and Central Patagonian Coast
}

\author{
Enrique A. Crespo, Susana N. Pedraza, Silvana L. Dans, Mariano Koen Alonso \\ Laura M. Reyes, Néstor A. García and Mariano Coscarella \\ Centro Nacional Patagónico (CONICET), Boulevard Brown s/n \\ 9120 Puerto Madryn, Chubut, Argentina \\ and \\ Adrián C. M. Schiavini \\ Centro Austral de Investigaciones Científicas (CONICET) \\ CC 92, 9410 Ushuaia, Tierra del Fuego, Argentina
}

\begin{abstract}
Since 1989, interactions between marine mammals and fisheries have been monitored along the Atlantic Patagonian coast. The Argentinian national fishing fleet in the area is composed of approximately 208 vessels (75\% trawlers; $16 \%$ jiggins; $9 \%$ longliners). The fleet operates the year-round from eight harbours between Escondida Island and San Jorge Gulf (80 000 naut. miles ${ }^{2}$ ). The important target species are: hake (Merluccius hubbsi), shortfin squid (IIlex argentinus) and shrimp (Pleoticus muelleri), while several tons of other fish are discarded. The dusky dolphin (Lagenorhynchus obscurus), the Commerson's dolphin (Cephalorhynchus commersonii) and the southern sea lion (Otaria flavescens) are incidentally caught. The dolphins become entangled mainly in mid-water trawls at night, while the sea lions become entangled in any kind of trawl. Annual mortality rates obtained are 170-480 sea lions (mostly males; figure estimated to be $1-2 \%$ of the population size in the area), 70-200 dusky dolphins (70\% females) and 25-170 Commerson's dolphins. Feeding habits of top predators, fish catch and bycatch of the fishery were also studied. Dusky dolphins in the area prey mainly on anchovy and squid, while hake was the most important food item for Commerson's dolphins and male southern sea lions. Squid is also important prey for sea lions and overlaps in size with the fish taken by the commercial fishery. Fishing areas for squid taken by jigging vessels overlap in part with those of foraging sea lions. Even though the commercial size for hake is $30 \mathrm{~cm}$ or larger, smaller hakes are largely discarded by the fishery. A combination of operational and specific interactions have been detected. At present, mortality rates seem to be low and there is insufficient evidence of competition for prey species. However, there is concern about the large amounts of fish (particularly hake) discarded by the fishery.
\end{abstract}

Key words: biological characteristics, fishery interactions, marine mammals, mortality, Southwest Atlantic

\section{Introduction}

Since 1974, the interactions between marine mammals and fisheries along the southwestern Atlantic Ocean off the coast of Uruguay have been studied (Brownell and Praderi, MS 1974; Crespo et al., 1986; Kasuya and Brownell, 1979; Praderi, MS 1976, MS 1979, MS 1982, MS 1983 and Praderi et al., 1989). The franciscana dolphin, Pontoporia blainvillei, was the species most often affected by incidental mortality in these small-scale fisheries. The same situation was observed involving the franciscana dolphin along the southern coast of Brazil by Pinedo $(1985,1986)$ and Praderi et al. (1989).

Preliminary surveys along the coast of Argentina were carried out between 1984 and 1986 by Pérez Macri and Crespo (1989) and by Crespo and Corcuera in 1990 (Crespo et al., 1994a, b, c), with 
the aim of studying the interactions between fisheries and franciscana dolphins and other cetacean species (mainly bottlenose dolphin Tursiops truncatus and dusky dolphin Lagenorhynchus obscurus). Mortality rates were only roughly estimated for P. blainvillei (Pérez Macri and Crespo, 1989). Fishery mortality of long-finned pilot whales Globicephala melas was also studied by Bastida and Lichtschein (1986). Southern Santa Cruz Province and Tierra del Fuego Island were surveyed by Goodall et al. (1994). Preliminary estimations of marine mammal mortality rates off Argentina were not very accurate nor complete, although detailed records of information were kept in several areas such as the Necochea-Claromecó area since 1988 and the coasts of Patagonia since 1989 (Monzón and Corcuera, 1990; Corcuera et al., 1994; Crespo et al., 1994a, b, c).

The biology of several marine mammal species in Argentina was studied mainly from specimens recovered from fisheries. The studies were directed towards specific interactions, particularly concerning predator-prey relationships, competition for common resources and transmission of parasites. The following studies were developed after the study of operational interactions: age and reproduction of franciscana dolphin, dusky dolphin, southern sea lion (Otaria flavescens), Burmeister's porpoise (Phocoena spinipinnis) and Commerson's dolphin (Cephalornynchus commersonii) (Corcuera and Monzón, 1990; Crespo et al., 1994d; Dans et al., 1993a,b; 1997; Monzón and Corcuera, 1990), physical maturity (Corcuera et al., 1994), feeding habits (Crespo et al., 1994c; Koen Alonso et al., 1993 a,b; 1998; Pérez Macri, 1986), parasites (Raga et al., 1990; Reyes et al., 1992, 1993) and chlorinated hydrocarbons (Borrel et al., 1990).

\section{Materials and Methods}

\section{Interviews with government officers and fishermen}

Information was recorded during interviews with fishermen from 88 vessels, mainly from the industrial fishery operating at Puerto Madryn, Comodoro Rivadavia, Puerto Deseado and Ushuaia. Information was also gathered, with less intensive effort, from the smaller harbours at Rawson, Camarones, Caleta Córdoba and southern coast of Santa Cruz Province. Additional information was obtained by reviewing files and by interviewing officers from the Fisheries Agencies at Chubut and Santa Cruz Provinces, and the National Coast Guard.

\section{Monitoring of fishing vessels}

The main characteristics of the fishing operations were recorded by direct observation at the harbours between the fishing trips, by monitoring a total of 20 vessels between 1992 and 1994. The duration of the fishing trips, the fishing area, type of gear, target species, fishing operations and marine mammal catches were recorded.

\section{Research trips and sampling on fishing vessels}

A total of 150 days were expended on board of fishing vessels by members of the research team in order to evaluate directly, cetacean sightings, incidental mortality and other by catch information.

By-catch information of the shrimp (Pleoticus muelleri) and the hake (Merluccius hubbsi) fisheries were also collected on board the vessels, with the objective of evaluating the species discarded and their relative abundance. For that purpose, 90$100 \mathrm{~kg}$ of fish and other species caught were sampled from each tow. Tows were sampled during morning, afternoon and evening operations. Each tow was sampled at the begining, in the middle and at the end of fish processing in order to avoid differences in fish catch composition within the net.

\section{Classification of the fishing types in the trawl- ing fishery}

In order to assess correctly the impact of the fishery on the marine mammal populations, the fishing fleet was classified into homogeneous components. Those fishing types were defined according to trawl type (bottom or mid-water trawl), gear (mesh size, size of the mouth of net), target species (hake and shrimp) and time of operation (diurnal or nocturnal activity). Preliminary estimates were made of nominal fishing effort for each fishing type. This was converted to the total number of fishing days per year by a summation of the individual days per vessel.

\section{Calculation of marine mammal by-catch}

The catch rates were calculated in three different ways:

1. Total catch rate $(T C R)$ :

$$
T C R=\frac{\sum_{i=1}^{n} m_{i}}{\sum t_{i}}
$$

where $m_{i}$ is the number of animals caught by the vessel $i$ during the survey, $t_{i}$ is fishing days of the vessel $i$ during the survey, 
and $n$ is the total number of vessels.

2. Average catch rate $(A C R)$ :

$$
A C R=\frac{\sum_{i=1}^{n} \frac{m_{i}}{t_{i}}}{n}
$$

where $A C R$ is the mean value of catch rate for individual vessels.

3. Maximum catch rate $(M C R)$ : when $M C R$ considers a uniform catch rate which is equal to the maximum individual vessel rate within a fishing type. It is calculated for a fishing type on the basis of the vessel with the highest catch rate, and applied to the remaining vessels of that type.

The number of animals caught annually was estimated by multiplying the catch rate by the nominal fishing effort for each type.

\section{Age and reproductive condition of the mammals caught by the fishery}

In order to know age and sex composition of the catches, age and reproductive status were determined for 25 dusky dolphins, 9 Commerson's dolphins and 7 southern sea lions incidentally caught in trawling nets in northern Patagonia. The specimens collected were usually frozen on board at $-20^{\circ} \mathrm{C}$.

Standard length was measured following Norris (1961). Several teeth were collected from each individual. After decalcifying them in $5 \%$ formic or nitric acid, haematoxylin-stained sections $16-18 \mu$ thick were obtained (Crespo et al., 1994d; Hohn, 1980; Perrin and Myrick, 1980). Growth layer groups in dentine and cementum were counted, assuming annual deposition.

During dissection, mammary glands were examined for presence of milk production and uterine horns were examined for the presence of foetuses. Ovaries were fixed in $10 \%$ formalin solution or Bouin's solution. The number of corpora lutea and corpora albicantia were counted by slicing the cortex at $2-3 \mathrm{~mm}$ intervals.

Each female was classified into the following categories according to Perrin and Donovan (1984): Immature: the female did not present corpora lutea or corpora albicantia; Mature: at least one corpus luteum or one corpus albicans was present; the latter category was further classified into resting, lactating, pregnant or pregnant and lactating females.

Testes were fixed in $10 \%$ formalin or Bouin's solution. After removal of the epididymides, each testis was weighed and measured by means of a caliper. An epididymal smear was taken in order to determine the stake of spermatozoa. By means of histological analysis and the prescence of sperm production, each male was classified into the following categories according to Hohn et al. (1985): immature, pubescent and mature.

\section{Stomach contents and relative importance of prey analysis}

The study of feeding habits was performed by examination of food remains in the stomachs of 20 dusky and 9 Commerson's dolphins and 24 southern sea lions. Dolphins were all caught by fishing vessels at San Jorge Gulf between 1989 and 1994, while most of them (73\%) were caught between 1992 and 1994. The sample of sea lions (11 males and 13 females) were both from fishing vessels and dead individuals collected in beaches and rookeries between $41^{\circ} \mathrm{S}$ and $47^{\circ} \mathrm{S}$. More than $70 \%$ were collected between 1991 and 1995 .

Prey species were identified by means of otoliths and bones in the case of fish, lower beaks of squid and exoskeletons of crustaceans. The importance of prey was studied by means of the Index of Relative Importance (IRI) (Pinkas et al., 1971), replacing the volume term by the percentage of the estimated weight (Castley et al., 1991).

Wet weight (W) of the prey was estimated from size based on regressions between measured $\mathrm{W}$ and size (total length, TL, for fish or dorsal mantle length, DML, for squid) and between size and measures of otoliths or beaks (otolith length, OL, lower rostral length, LRL, or lower hood length, LHL) (Clarke, 1986; George-Nascimento et al., 1985; Pinedo, MS 1982).

The study of overlap in the use of resources was carried out by means of the Adjusted General Overlap Index (GOa) (Ludwig and Reynolds, 1988; Petraitis, 1979). The null hypothesis of the complete overlap was tested by using the V statistic (Ludwig and Reynolds, 1988). The overlap analysis between marine mammals and fisheries was restricted to the important prey items in the diet of 
the mammals. In order to analyze the use of common resources, prey species were categorized in size-classes as follows:

1) The hake (M. hubbsi) was divided into three categories: a) primary juveniles less than $12 \mathrm{~cm}$ TL; b) secondary juveniles between 12 and $30 \mathrm{~cm}$; c) preadults and adults more than $30 \mathrm{~cm}$ (Angelescu and Prenski, 1987).

2) The shortfin squid (I. argentinus) was divided into two categories: a) less than $20 \mathrm{~cm}$ DML; b) more than $20 \mathrm{~cm}$ DML (commercial size).

3) The patagonian squid (Loligo gahi) was included in only one category because almost all sizes can be marketed and even small individuals are caught by the trawling fishery (personal observations).

4) The southern anchovy (Engraulis anchoita) was divided into two categories: a) juveniles less than $10 \mathrm{~cm} \mathrm{TL}$; and b) preadults and adults more than $10 \mathrm{~cm}$ TL (Angelescu, 1982) (commercial size).

\section{Results}

\section{Description of the highseas fisheries}

Fisheries along the coast of Patagonia involve five ports at Chubut Province (Puerto Madryn, Puerto Rawson, Camarones, Caleta Córdoba and Comodoro Rivadavia), two at Santa Cruz Province (Puerto Deseado and Punta Quilla) and one at Tierra del Fuego Province (Ushuaia). Most of the larger vessels operated from Puerto Madryn and Puerto Deseado (Table 1). It should be mentioned that an unknown number of fishing vessels operated from northern harbours (e.g. Mar del Plata in Buenos Aires Province) and foreign vessels that fished on the border of the Exclusive Economic Zone (EEZ).

The Argentinian Government agencies classify fishing vessels into four categories, which are: Close Coastal (CC), Distant Coastal (DC), Freezing (FZ) and Factory (F) vessels, which differ one from another by vessel length, engine power, fish processing and freezing hold capacity. The most common fishing gear in the north and central Patagonia was the trawl, which was used by around $80 \%$ of all fishing vessels. Two other fishing gear, jigging and longlining, were used by a small number of freezing vessels (19 and 34 from a total of
208 for 1995, respectively) (Table 1). It should be noted that in the last two years the number of foreing jigging vessels increased over this figure.

\section{The trawling fishery}

The trawling fishery up to 1995 included, 155 vessels of which 149 operated in northern and central Patagonia (Table 2) from all fishing harbours with the exception of Ushuaia, from which the remaining six vessels operated.

The most important target species for the trawling fleet in the northern and central region included: shrimp and hake. Other associated species of commercial importance were shortfin squid, patagonian squid, Brazilian sandperch (Pseudopercis semifasciata), pink cusk-eel (Genypterus blacodes), grouper (Acanthistius brasilianus), sole (Paralichthys sp.), southern anchovy, parona leatherjack (Parona signata) and blackbelly rosefish (Helicolenus lahillei).

The most important fishing grounds for this fleet were located in the following areas: Escondida Island $\left(43^{\circ} 30^{\prime}-44^{\circ} \mathrm{S} ; 64^{\circ}-65^{\circ} 18^{\prime} \mathrm{W}\right)$, Bajo de los Huesos $\left(43^{\circ}-43^{\circ} 30^{\prime} \mathrm{S} ; 6^{\circ}-65^{\circ} \mathrm{W}\right)$, North of $\mathrm{San}$ Jorge Gulf and Camarones Bay $\left(44^{\circ}-46^{\circ} \mathrm{S} ; 65^{\circ}-\right.$ $\left.67^{\circ} \mathrm{W}\right)$, South of San Jorge Gulf $\left(46^{\circ}-47^{\circ} \mathrm{S} ; 65^{\circ}-\right.$ $\left.66^{\circ} \mathrm{W}\right)$ and Puerto Deseado $\left(46^{\circ}-48^{\circ} \mathrm{S} ; 62^{\circ}-65^{\circ} \mathrm{W}\right)$.

The vessels showed a different spatial and temporal distribution depending on the target species; those fishing for hake operated farther from the coast and moved northward during summer (Fig. 1), while those fishing for shrimp operated closer to the coast and remained in the same area the whole year (Fig. 2)

Additionaly, six large factory vessels operated from Ushuaia fishing for Patagonian grenadier (Macruronus magellanicus) and southern blue whiting (Micromesistius australis) for "surimi" (midwater and bottom trawlers). Fishing areas were located between Burwood Bank and the shelf between Malvinas island and Tierra del Fuego.

The trawling fleet used two different types of net: a) one conventional net operated from the stern (66\% of the trawlers); b) two smaller nets operated from the sides of the vessel by means of a two-rig system (34\% of the trawlers). The latter was used exclusively to catch shrimp. The mesh sizes of the bag (stretched) were $12 \mathrm{~cm}$ and $6 \mathrm{~cm}$ for hake and 
TABLE 1. Composition of the fishing fleet operating from mayor harbours in Patagonia up to 1995, according to vessel type (CC: close coastal, DC: distant coastal, FZ: freezing, F: factory) and fishing gear (TRW: trawling, LL: longline, JG: jigging).

\begin{tabular}{|c|c|c|c|c|c|c|c|}
\hline $\begin{array}{l}\text { Type of Vessel: } \\
\text { Fishing Gear: }\end{array}$ & $\begin{array}{c}\mathrm{CC} \\
\mathrm{TRW}\end{array}$ & $\begin{array}{c}\text { DC } \\
\text { TRW }\end{array}$ & TRW & $\begin{array}{l}\text { FZ } \\
\text { LL }\end{array}$ & JG & $\begin{array}{c}\mathrm{F} \\
\mathrm{TRW}\end{array}$ & Total \\
\hline \multicolumn{8}{|l|}{ Harbour: } \\
\hline Puerto Madryn & - & 5 & 25 & 4 & 14 & 13 & 61 \\
\hline Comodoro Rivadavia & 2 & 15 & 3 & - & - & - & 20 \\
\hline Rawson & 21 & 13 & - & - & - & - & 34 \\
\hline Caleta Córdova & 6 & - & - & - & - & - & 6 \\
\hline Puerto Deseado & - & - & 39 & 7 & 20 & 7 & 73 \\
\hline Ushuaia & - & - & - & 8 & - & 6 & 14 \\
\hline Total & 29 & 33 & 67 & 19 & 34 & 26 & 208 \\
\hline
\end{tabular}

TABLE 2. Characteristics of the trawling vessels operating from Patagonian harbours up to 1995. Standard deviations are presented in parenthesis below the value.

\begin{tabular}{|c|c|c|c|c|c|c|}
\hline $\begin{array}{l}\text { Type of } \\
\text { Vessel }\end{array}$ & $\begin{array}{l}\text { Length } \\
\qquad(\mathrm{m})\end{array}$ & $\begin{array}{l}\text { DSP } \\
\text { (ton) }\end{array}$ & $\begin{array}{l}\text { Main engine } \\
\text { (HP) }\end{array}$ & $\begin{array}{c}\text { Main Values } \\
\text { Hold } \\
\left(\mathrm{m}^{3}\right)\end{array}$ & $\begin{array}{c}\text { Year of } \\
\text { construction }\end{array}$ & $\begin{array}{c}\text { Trip duration } \\
\text { (days) }\end{array}$ \\
\hline $\begin{array}{l}\text { Close coastal } \\
\quad n=29\end{array}$ & $\begin{array}{r}16 \\
(2)\end{array}$ & $\begin{array}{r}28 \\
(14)\end{array}$ & $\begin{array}{r}186 \\
(89)\end{array}$ & $\begin{array}{r}28 \\
(16)\end{array}$ & $\begin{array}{r}1955 \\
(21)\end{array}$ & 0.5 \\
\hline $\begin{array}{l}\text { Distant coastal } \\
\mathrm{n}=33\end{array}$ & $\begin{array}{l}27 \\
(7)\end{array}$ & $\begin{array}{r}158 \\
(143)\end{array}$ & $\begin{array}{r}532 \\
(277)\end{array}$ & $\begin{array}{r}154 \\
(103)\end{array}$ & $\begin{array}{r}1977 \\
(12)\end{array}$ & $\begin{array}{r}4.5 \\
(1.7)\end{array}$ \\
\hline $\begin{array}{l}\text { Freezing } \\
\quad \mathrm{n}=67\end{array}$ & $\begin{array}{r}36 \\
(8)\end{array}$ & $\begin{array}{r}310 \\
(180)\end{array}$ & $\begin{array}{l}1041 \\
(427)\end{array}$ & $\begin{array}{r}293 \\
(178)\end{array}$ & $\begin{array}{r}1979 \\
(9)\end{array}$ & $\begin{array}{r}33.9 \\
(5.5)\end{array}$ \\
\hline $\begin{array}{c}\text { Factories } \\
n=20\end{array}$ & $\begin{array}{r}74 \\
(10)\end{array}$ & $\begin{array}{l}1592 \\
(828)\end{array}$ & $\begin{array}{r}2918 \\
(1061)\end{array}$ & $\begin{array}{r}1663 \\
(1004)\end{array}$ & $\begin{array}{r}1971 \\
(5)\end{array}$ & $\begin{array}{r}48.1 \\
(11.3)\end{array}$ \\
\hline
\end{tabular}

shrimp trawl nets, respectively. The nets were made of nylon multifilament. Small vessels carry on board only one net. Vessels over $30 \mathrm{~m}$ length carry more than one net which are ready to be changed when sailing. The larger vessels (FZ and F) carry an echosounder and all, except of $\mathrm{CC}$, have detection equipment.

\section{Fishing types and nominal fishing effort for the trawling fishery}

Nine types were defined as follows for the trawling fleet studied (northern and central Patagonian coast):

Type 1. Used during diurnal bottom trawling by $\mathrm{CC}$ vessels. The mouth of the net is 1.5 $\mathrm{m}$ high and $8 \mathrm{~m}$ wide, and the target species are hake and shrimp.
Type 2. Used during diurnal bottom trawling by DC vessels. The mouth of the net is $3 \mathrm{~m}$ high and $25 \mathrm{~m}$ wide, and the target species is hake.

Type 3. Used during diurnal bottom trawling by $\mathrm{FZ}$ and F vessels. The mouth of the net is $3 \mathrm{~m}$ high and $42 \mathrm{~m}$ wide, and the target species is shrimp.

Type 4. Used during diurnal bottom trawling by $\mathrm{F}$ vessels. The mouth of the net is $3.5 \mathrm{~m}$ high and $49 \mathrm{~m}$ wide, and the target species are hake, grouper, Brazilian sandperch, pink cusk-eel and squid.

Type 5. Used during diurnal bottom trawling by two-rig system FZ vessels. Each net has a mouth 0.8 to $1.5 \mathrm{~m}$ high and $28 \mathrm{~m}$ wide, and the target species is shrimp. 


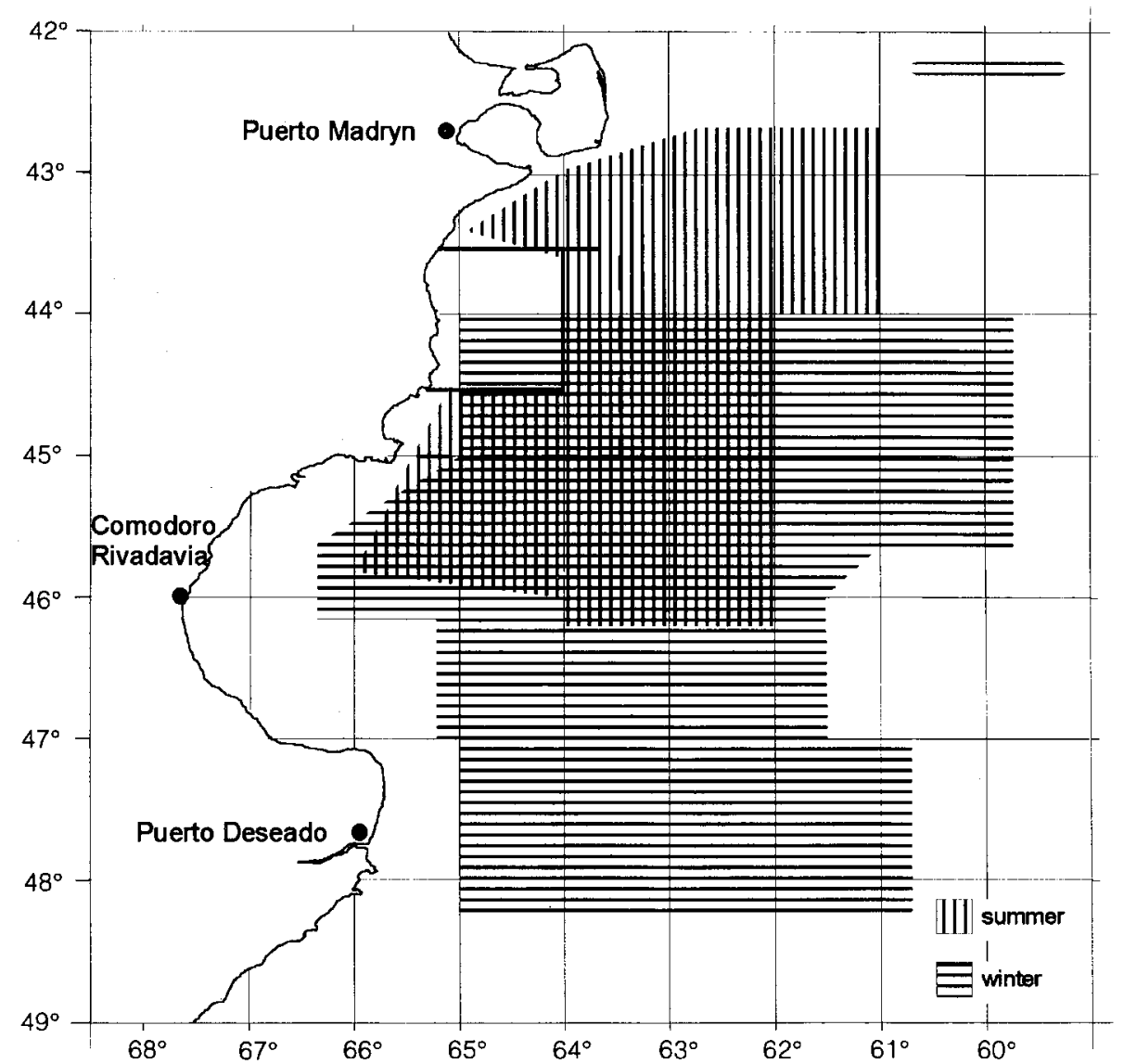

Fig. 1. Fishing areas of the Patagonian trawling fleet operating for hake (Merluccius hubbsi) during summer (September-February) and winter (March-August) between 1992 and 1995.

Type 6. Used during diurnal bottom trawling by $F$ vessels. The mouth of the net is $5 \mathrm{~m}$ high and $42 \mathrm{~m}$ wide, and the target species are hake, grouper, Brazilian sandperch, pink cusk-eel and squid.

Type 7. Used during diurnal bottom trawling by factory vessels. The mouth of the net is $7 \mathrm{~m}$ high and $52 \mathrm{~m}$ wide, and the target species is shrimp.

Type 8. Used during nocturnal mid-water trawling by factory vessels. The mouth of the net is $20 \mathrm{~m}$ high and $40 \mathrm{~m}$ wide, and the target species is shrimp.

Type 9. Used during nocturnal mid-water trawling by factory vessels. The mouth of the net is $42 \mathrm{~m}$ high and $42 \mathrm{~m}$ wide, and the target species is hake.
The total number of effective fishing days per year of the Patagonian trawling fishery was 39213 days/year for a total of 149 fishing vessels. Fishing Type 5 accounted for almost half of the total fishing effort (40\%), followed in importance by Type $2(26 \%)$, Type $4(13 \%)$ and Type $1(7 \%)$ (Fig. 3).

\section{The national and foreign fleet for squid}

The fleet for squid jigging consisted of at least 110 vessels in 1995. Part of this fleet consisted of 34 national vessels operating from Patagonian harbours (Table 1) and 50 or more foreign vessels operating from these and other harbours. All these vessels fished inside the EEZ of Argentina. Outside the EEZ, an international fleet mainly composed of jigging vessels operated on the continental shelf. An estimated number of vessels operating 


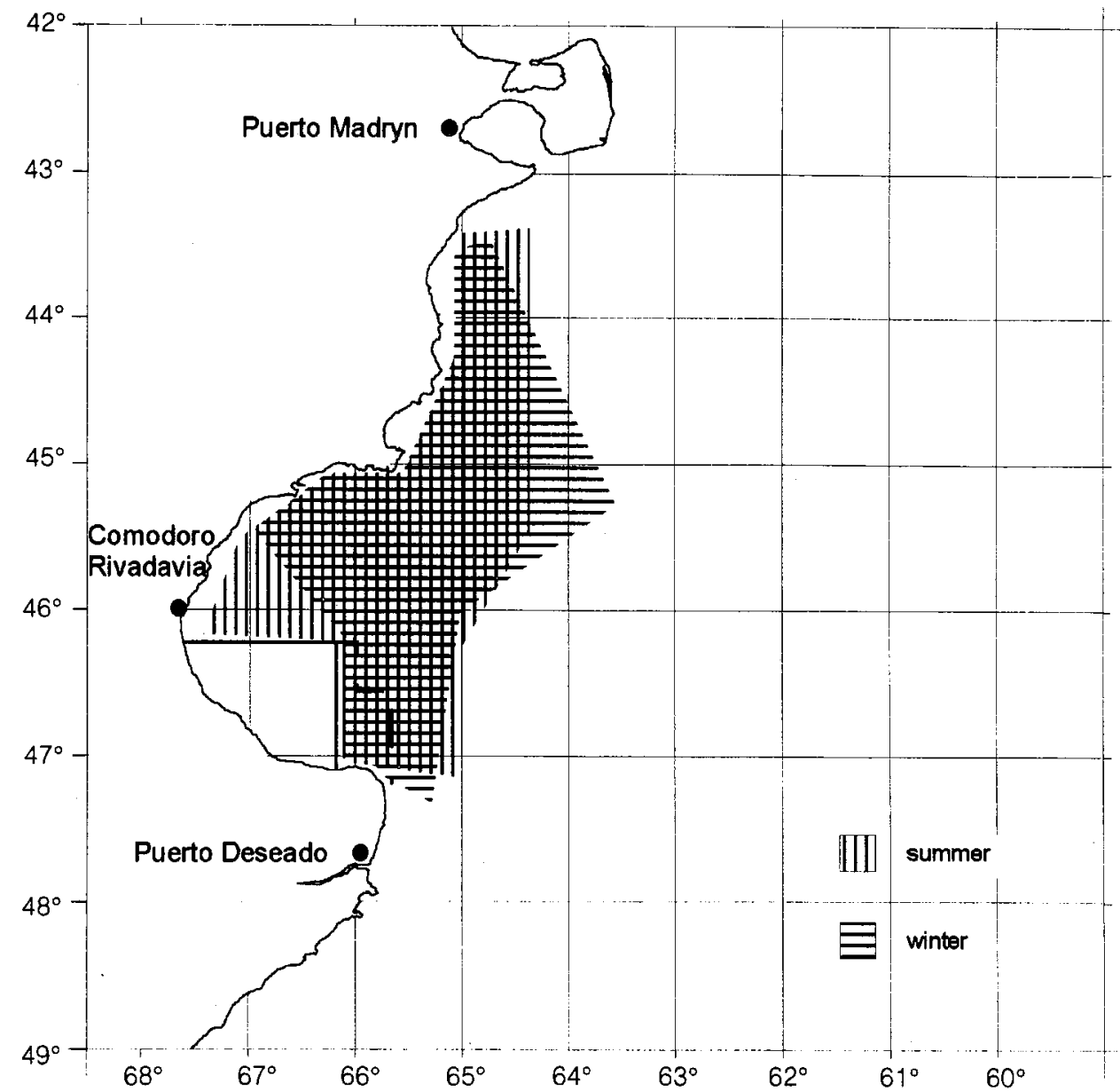

Fig. 2. Fishing areas of the Patagonian trawling fleet operating for shrimp (Pleoticus muelleri) during summer (September-February) and winter (March-August) between 1992 and 1995.

in this area were no less than 150 (Anonymous, 1994).

The target species were shortfin squid and black squid (Martialia hyadesi), which are found alone or in mixed groups, and the Patagonian squid was also caught. Areas for squid jigging ranged from Mar del Plata $\left(38^{\circ} \mathrm{S}\right)$ to San Sebastián Bay $\left(53^{\circ} \mathrm{S}\right)$, from the $100 \mathrm{~m}$ isobath in the continental shelf to the continental slope. The fishing vessels operated in the south during summer and moved farther north during the course of the year (Fig. 4).

Recently, records of interactions between the jigging fishery and marine mammals have been recorded, but not quantified. Southern sea lions and Commerson's dolphins are reported to entangle lines of jigging machines, prey on squid, and scatter the schools.

\section{The longline fishery}

The longline fleet was composed in 1995 of at least 19 vessels operating in two separate fishing areas from Puerto Madryn, Puerto Deseado and Ushuaia (Fig. 5).

The target species included Patagonian toothfish (Dissostichus eleginoides), pink cusk-eel and hake. The bait used for longlines was mainly squid. Fishing areas for Patagonian toothfish were mainly at Burwood Bank, neighbouring areas off Tierra del Fuego, Staten Island and South Georgias Islands, and the continental slope up to $47^{\circ} \mathrm{S}$. Fishing area for pink cusk-eel and the hake was from Rawson $\left(43^{\circ} \mathrm{S}\right)$ to Puerto Deseado $\left(47^{\circ} \mathrm{S}\right)$ and from $64^{\circ} \mathrm{W}$ to the continental slope.

The number of vessels fishing for Patagonian toothfish increased because of high commercial 


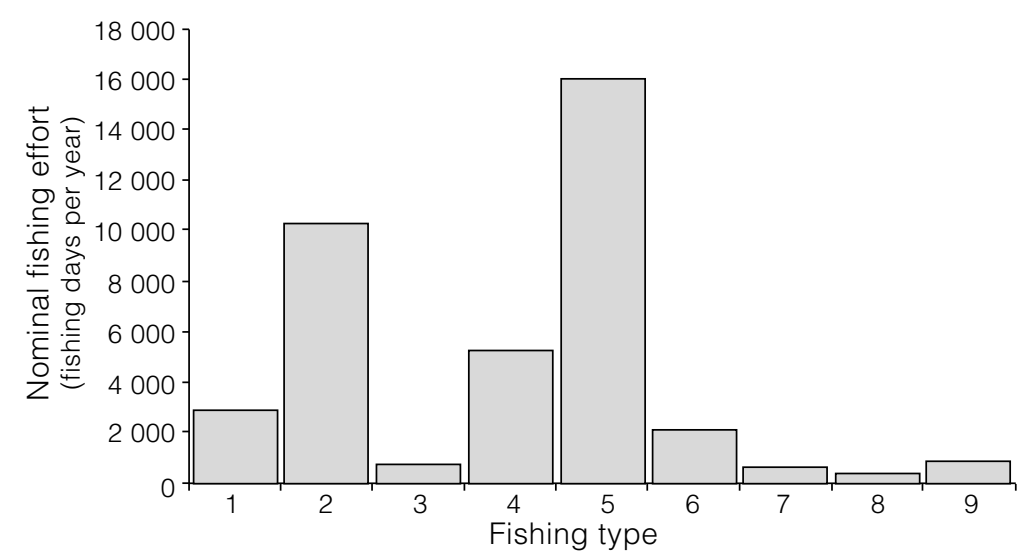

Fig. 3. Distribution of the annual fishing effort deployed by the Patagonian trawling fleet (Fishing Types 1 to 9) operating in northern and central region during 1992 to $1994(\mathrm{n}=149)$.

demand. Associated species included Patagonian hake (Merluccius australis), dogfish (Squalus sp.), Patagonian smoothhound (Mustelus schmitti), Brazilian sandperch, grouper, Patagonian cod (Salilota australis), blackbelly rosefish and rays.

Close to Tierra del Fuego, killer whales (Orcinus orca) and sperm whales (Physeter macrocephalus) have been reported to steal bait and catches from longlines. These operational interactions have not yet been quantified.

\section{Estimation of marine mammals caught in the trawling fishery}

Out of the 149 fishing vessels operating in the northern and central Patagonian coast, 20 trawlers (Types 2-8) were monitored continuously; the vessels were selected on the basis of the credibility of fishing officers. From March 1992 to June 1994, an estimated total of 97 marine mammals were incidentally caught, during a total of 5761 fishing days for the monitored fishing vessels.

Southern sea lion catches were recorded in the seven fishing Types. Dusky dolphins were caught by three different fishing types while Commerson's dolphins were caught by only two fishing types (Table 3). The estimated number of specimens caught by the fishery varied depending on the different calculations carried out. The specimens caught ranged from 175 to 601 southern sea lions, 69 to 215 dusky dolphins, and 25 to 171 Commerson's dolphins.
Analysis of the age and reproductive condition of the animals caught by the trawling fishery

Southern sea lion. For southern sea lions, a catch bias existed towards young males. The ageclasses in the sample ranged from young males (1 year old) to adult males ( 8 or more years old), with an average age of $3.1 \pm 2.9$ years. Two adult females were recovered. One of them was 14 years old, probably pregnant due to the presence of a corpus luteum. The other female recovered was 18 years old and lactating.

Dusky dolphin. The ages in the sample of incidentally caught dolphins ranged from 0 to 11 years. The sample was biased toward females $(70 \%$ of the catch). Among the eighty females, eight were mature $(44 \%)$ of which four were pregnant $(50 \%)$. The average age of the females was $5.9 \pm 2.1$ years. There were seven males in the sample, two of which were determined as immature animals including one newborn calf. Of the other five males in the sample, four were determined as mature, judged by testicular weights and sperm production. All of these males were 8 years old or more. The average age of the males was $7.2 \pm 3.2$ years.

Commerson's dolphin. Even though the sample was small (9), a high percentage of the individuals were females (7), indicating a bias in the catch. Among the four mature females three were in the resting stage and one was lactating. There were no pregnant females in the sample. The average age was $8.7 \pm 4.1$ years (range $3-14$ ). Only two males were found, age 7.5 and 10 years. 


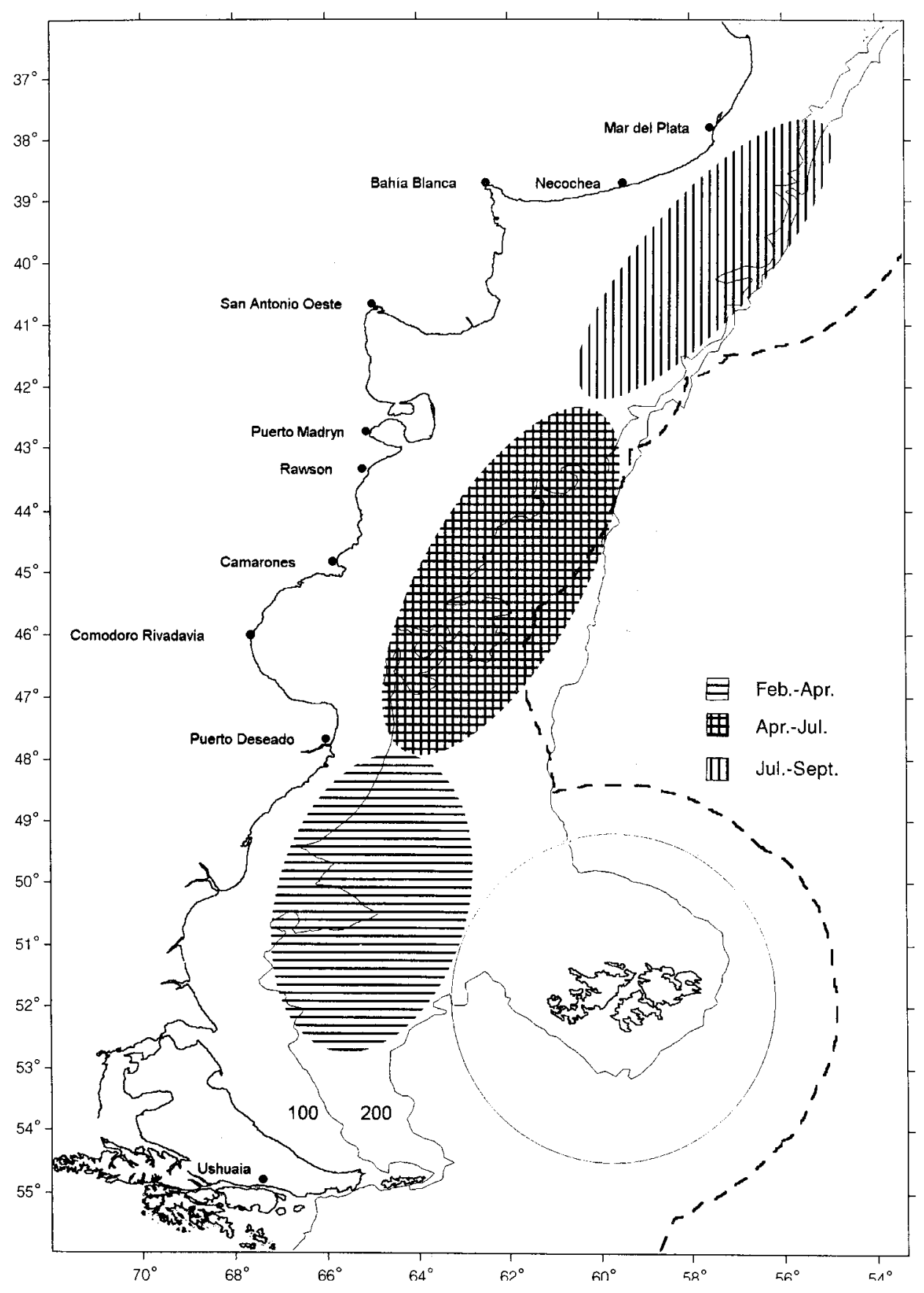

Fig. 4. Fishing areas for jigging vessels operating off Patagonia between 1992-95.

\section{Analysis of marine mammals feeding habits}

Twenty seven prey species were found in the stomachs contents of three marine mammal species studied, and fish accounted for 17 species. The most important prey items included hake, shortfin squid, southern anchovy and Patagonian squid (Fig. 6).
Twenty one prey species were found in male sea lions and 18 were found in females. The spectrum of important prey items was more restricted for males than for females. The most important prey items for males included hake, and shortfin and Patagonian squids. Four important prey species appeared to be dominant in females: shortfin squid, 


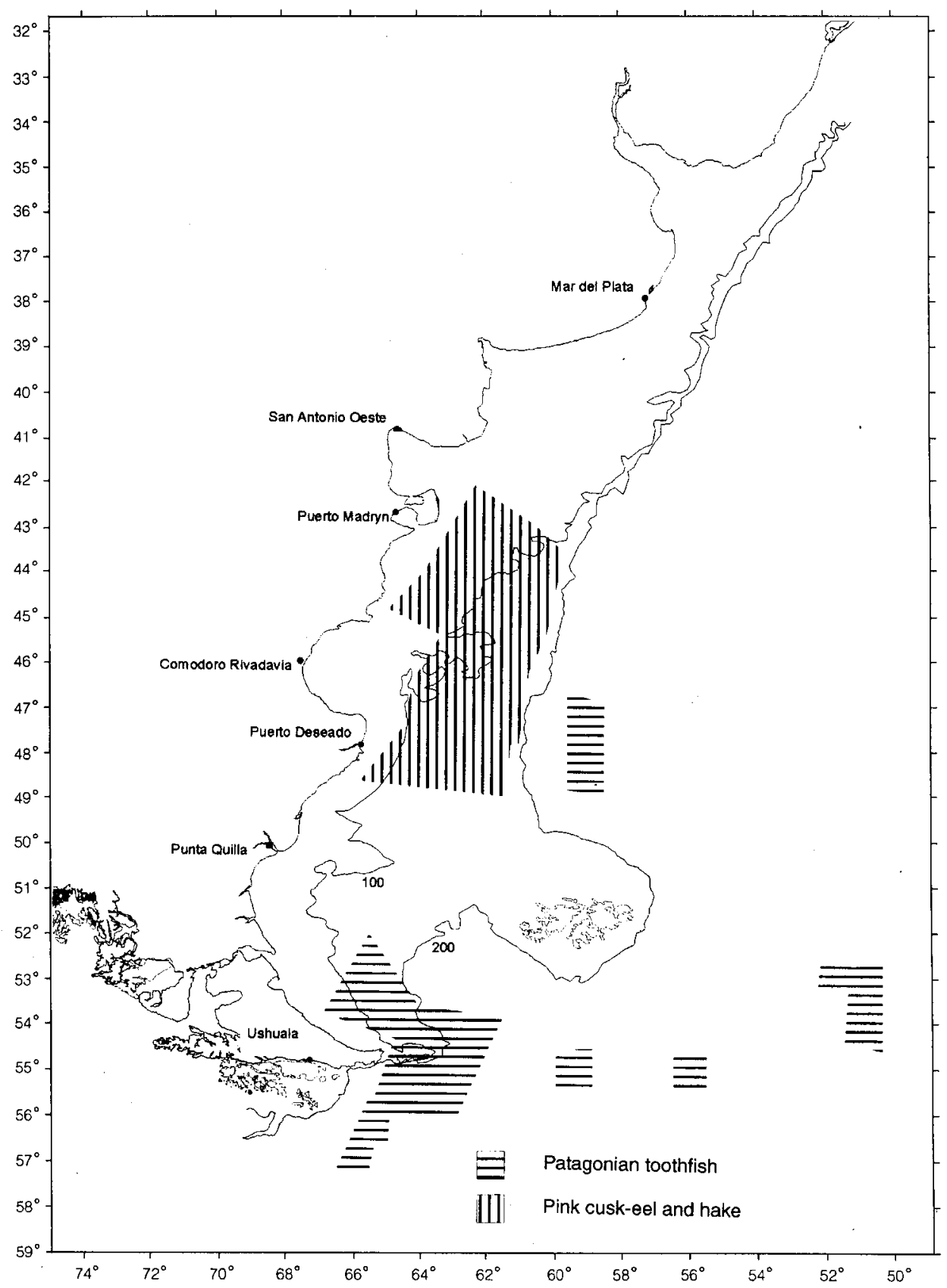

Fig. 5. Fishing areas for longline vessels operating off Patagonia between 1992-95.

hake, "raneya" (Raneya flumnensis) and red octopuss (Enteroctopus megalocyathus) (Fig. 6).

With respect to the delphinid species, the prey collection was more restricted than that of the southern sea lion ( 8 species for the dusky dolphin and 9 for Commerson's dolphin). Most important prey species for dusky dolphin included anchovy, shortfin and Patagonian squid and hake in decreasing order. In the Commerson's dolphins, hake seemed to be a preferred species followed by the shortfin squid, while dusky dolphins had a more evenly distributed food selection (Fig. 6).

The results obtained suggested that hake is the most important prey for the marine mammals stud- 
TABLE 3. Estimated catch rates (TCR: total catch rate, ACR: Average catch rate (standard deviations in parenthesis), MCR: Maximum catch rate) and total number of southern sea lions, dusky dolphins and Commerson's dolphins annually caught in trawls off Patagonia during 1992-94.

\begin{tabular}{|c|c|c|c|c|c|c|c|}
\hline Fishing type & $\begin{array}{l}\text { Annual effort } \\
\text { (days) }\end{array}$ & TCR & Total per year & ACR & Total per year & MCR & Total per year \\
\hline \multicolumn{8}{|c|}{ Sea lion } \\
\hline 2 & 10297 & 0.01014 & 104 & $\begin{array}{r}0.0108 \\
(0.01350)\end{array}$ & 111 & 0.03810 & 392 \\
\hline 3 & 743 & 0.00775 & 6 & 0.00775 & 6 & 0.00775 & 6 \\
\hline 4 & 5270 & 0.00250 & 13 & $\begin{array}{r}0.0036 \\
(0.00630)\end{array}$ & 19 & 0.01100 & 58 \\
\hline 5 & 16068 & 0.00196 & 31 & $\begin{array}{r}0.00188 \\
(0.00250)\end{array}$ & 30 & 0.00625 & 100 \\
\hline 6 & 2135 & 0.00492 & 11 & $\begin{array}{r}0.0063 \\
(0.00880)\end{array}$ & 13 & 0.01660 & 35 \\
\hline 7 & 610 & 0.00548 & 3 & 0.0055 & 3 & 0.00548 & 3 \\
\hline 8 & 366 & 0.01813 & 7 & 0.0181 & 7 & 0.01813 & 7 \\
\hline Total & & & 175 & & 189 & & 601 \\
\hline \multicolumn{8}{|c|}{ Dusky dolphin } \\
\hline 2 & 10297 & 0.00068 & 7 & $\begin{array}{r}0.00095 \\
(0.00301)\end{array}$ & 10 & 0.00952 & 98 \\
\hline 5 & 16068 & 0.00049 & 8 & $\begin{array}{r}0.00039 \\
(0.00120)\end{array}$ & 6 & 0.00390 & 63 \\
\hline 8 & 366 & 0.14804 & 54 & 0.14804 & 54 & 0.14804 & 54 \\
\hline Total & & & 69 & & 70 & & 215 \\
\hline \multicolumn{8}{|c|}{ Commerson's dolphin } \\
\hline 2 & 10297 & 0.00135 & 14 & $\begin{array}{r}0.00155 \\
(0.0049)\end{array}$ & 16 & 0.01550 & 160 \\
\hline 8 & 366 & 0.03021 & 11 & 0.03021 & 11 & 0.03021 & 11 \\
\hline Total & & & 25 & & 27 & & 171 \\
\hline
\end{tabular}

ied followed by the shortfin squid, the Patagonian squid and the southern anchovy.

\section{Analysis of the use of common resources}

The preliminary information gathered on hake sizes caught by the hake fishery (one shipment carried out in winter; intermediate continental shelf, mesh size $12 \mathrm{~cm}$ ) suggested that the fishery caught sizes above $20 \mathrm{~cm}$ of TL with a mode in $30 \mathrm{~cm}$ TL and range $20-50 \mathrm{~cm}$ (Fig. 7). Hake was also caught as by-catch in the shrimp fishery. In this case the fish ranged from 10 to $50 \mathrm{~cm}$ of TL (two shipments during winter, mesh size $6 \mathrm{~cm}$ ). The analysis of hake sizes sampled revealed smaller hakes in coastal areas (northern San Jorge Gulf) than caught at the intermediate continental shelf (eastern Mazarredo).
In the former case a mode was found around $20 \mathrm{~cm}$ of TL, while a bimodal distribution at 20 and 35 $\mathrm{cm}$, respectively, was found in the latter (Fig. 7).

Most of the hake consumed by the sea lions belonged to sizes caught by the fishery, even though only a part of it consisted of commercial sizes (Fig. 7). Dusky dolphins consumed hake of similar sizes, overlapping in part with both male and female sea lions. The Commerson's dolphin consumed smaller sizes of hake than taken by the fishery (Fig. 7).

With respect to the shortfin squid, both dolphin species fed on non-commercial sizes, while the sea lions fed on larger sizes (commercial and non-commercial) (Fig. 8). 


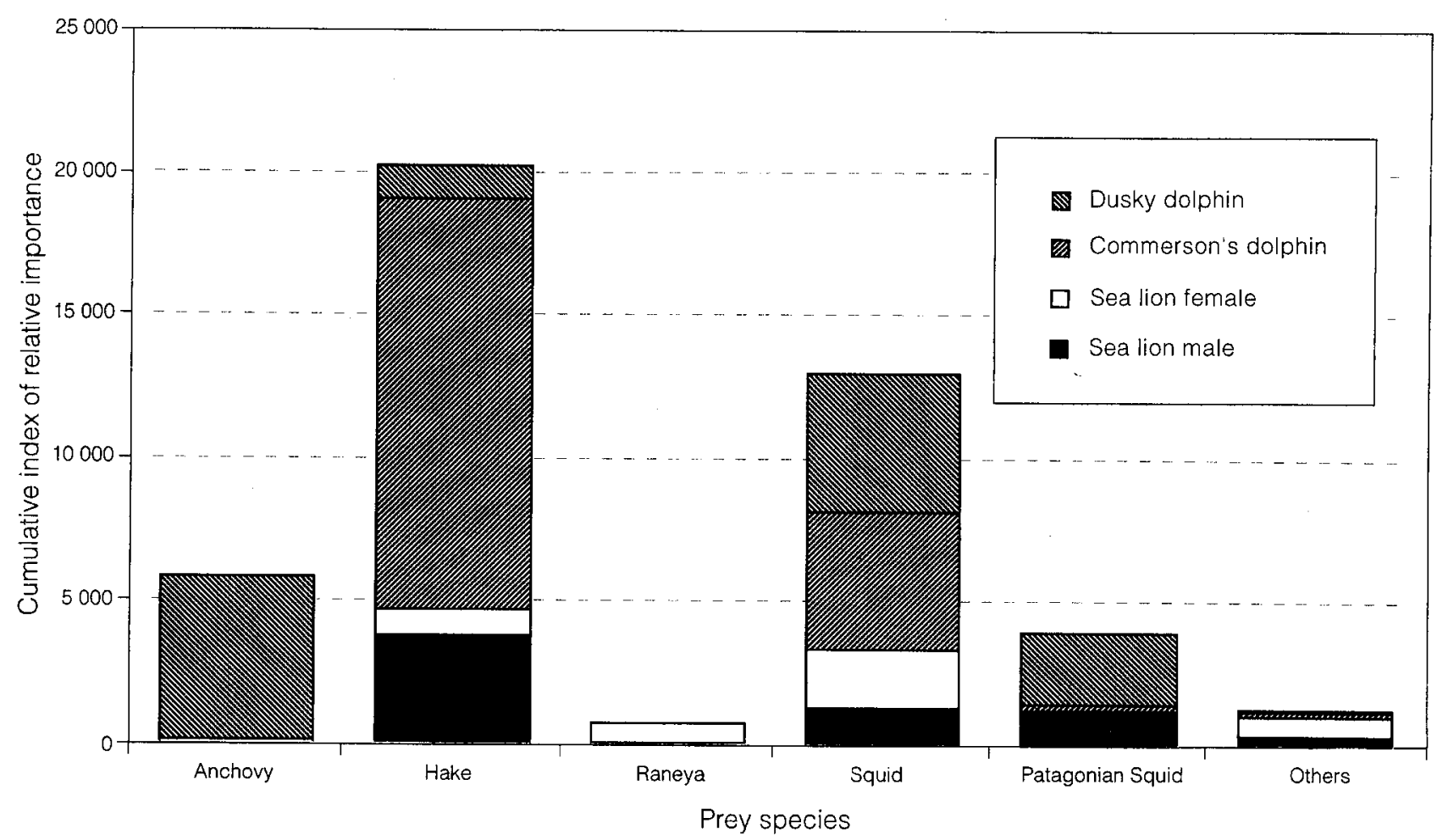

Fig. 6. Cumulative index of relative importance (IRI) of southern sea lion, dusky and Commerson's dolphins' preys off Patagonia.

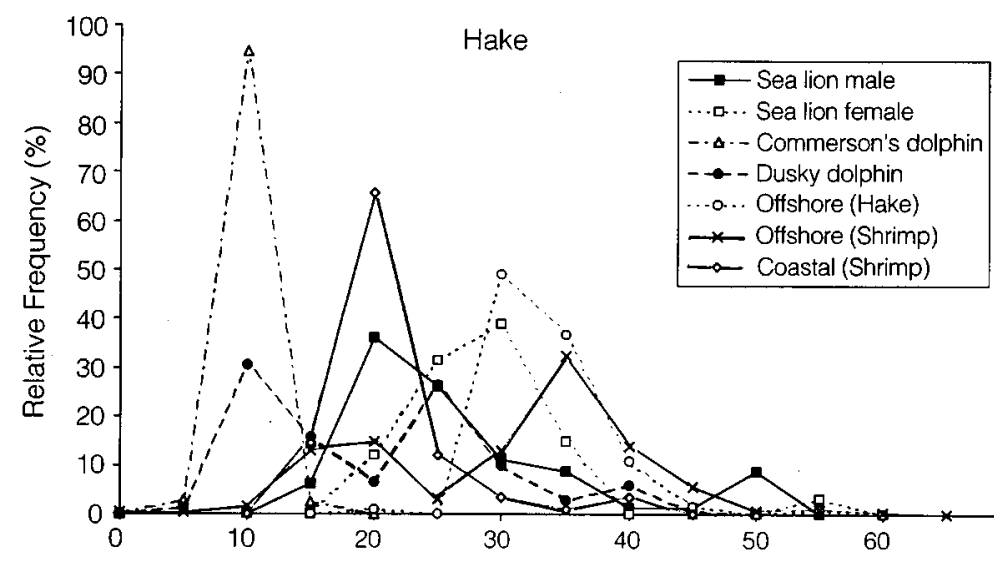

Fig. 7. Size frequency distribution of hake caught by top predators (sea lion male and female, dusky dolphin, Commerson's dolphin, offshore hake fishery, offshore shrimp fishery and coastal shrimp fishery) off Patagonia.

Other important prey for marine mammals were the Patagonian squid and the southern anchovy. Both species are caught as by-catch in the shrimp fishery in the northern San Jorge Gulf, with sizes ranging from 4 to $20 \mathrm{~cm}$ of DML and above $10 \mathrm{~cm}$ of TL (Fig. 9). 


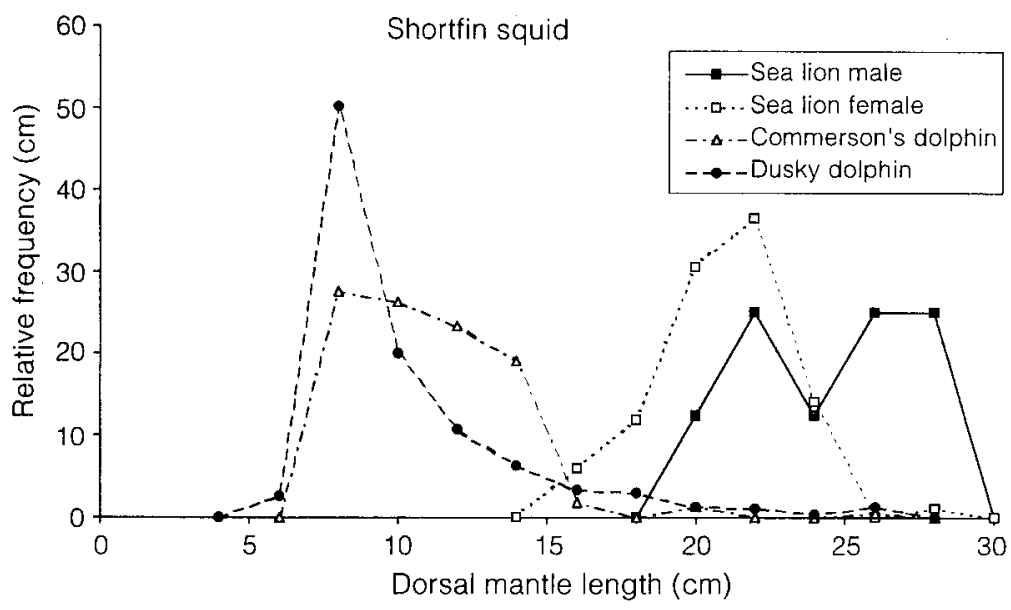

Fig. 8. Size frequency distribution of shortfin squid caught by top predators (sea lion male and female, dusky dolphin and Commerson's dolphin) off Patagonia.

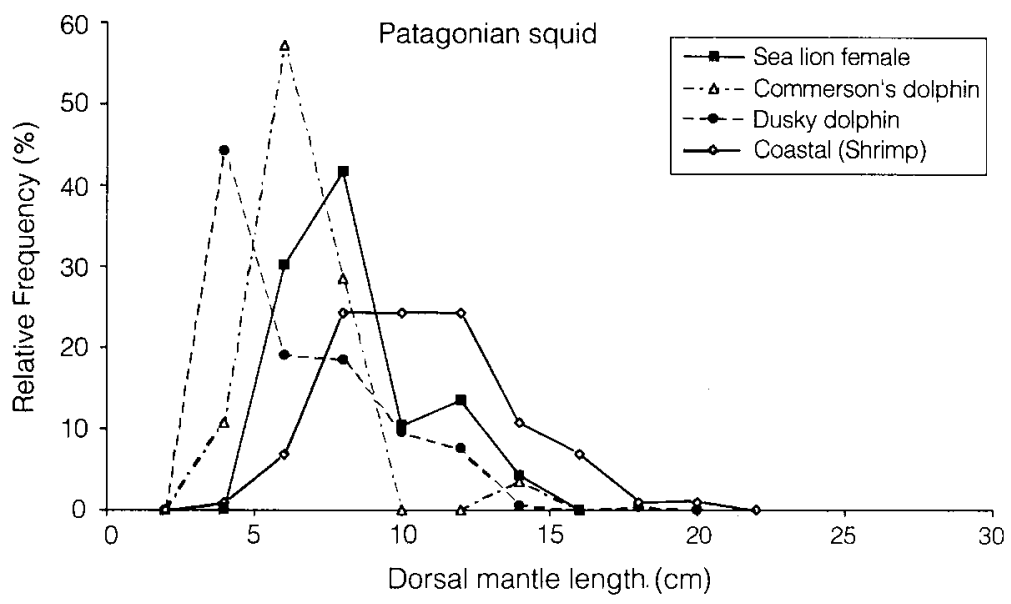

Fig. 9. Size frequency distribution of patagonian squid caught by top predators (sea lion male, Commerson's dolphin, dusky dolphin, coastal shrimp fishery) off Patagonia.

Considering both sexes of the sea lion, dusky dolphin, Commerson's dolphin and coastal and offshore samples taken from the shrimp fishery as different predators, a preliminary common resources utilization curve with the most important prey for marine mammals was constructed (Fig. 10), and GOa was calculated using these data. The general overlap between all predators together was low $(\mathrm{GOa}=0.221)$ and significantly different with re- spect to the complete overlap $(\mathrm{V}=13848.1 \mathrm{df}=30$ $\mathrm{p}<0.05)$. The overlaps between marine mammals and samples from the shrimp fishery taken by pairs, was different with respect to the complete overlap (Table 4). The extreme points were the high overlap between sea lion males and coastal samples $(\mathrm{GOa}=0.913)$ on the one hand and the low overlap between Commerson's dolphin and the offshore sample $(\mathrm{GOa}=0.042)$ on the other $($ Table 5$)$. 


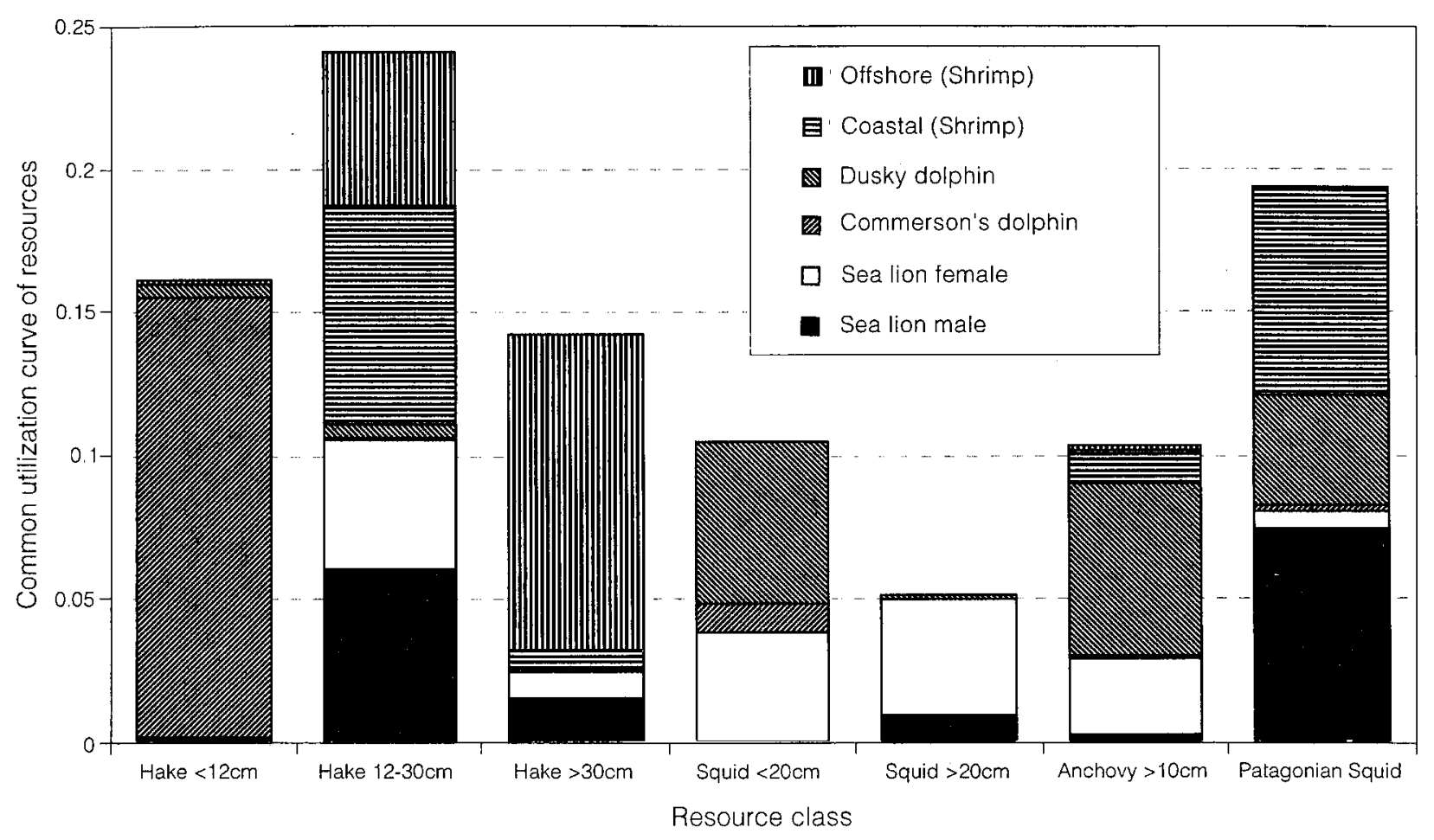

Fig. 10. Common Utilization Curve of Resources constructed considering hake (3 categories), shortfin squid (2 categories), patagonian squid (1 category) and southern anchovy (1 category).

\section{Discussion}

The historical evidence about the development of fisheries on the Patagonian shelf, and the effects on marine mammal populations and the environment in general, began in the early-1970s. Fishing for hake and shrimp by means of trawling led to the introduction of larger freezing and factory vessels, the use of which expanded continuously throughout the fishing areas. Changes have occured in the fleet during the last 25 years, increasing the probability of entanglement of marine mammals. The fishing effort continued to increase at the beginning of the 1990s with the incorporation of jigging and longline vessels in fishing areas not previously exploited (Crespo et al., 1994a, b).

The hake fishery (conventional trawlers) take place between Península Valdés and Puerto Deseado, between 15 and 120 naut. miles from the coast (Fig. 1). The shrimp fishery (two-rig system trawlers) is more coastal (within 80 naut. miles) fishing between Escondida Island and San Jorge Gulf (Fig. 2). Fishing for Patagonian grenadier
(Macruronus magellanicus) and southern blue whiting (Micromesistius australis) for "surimi" (midwater and bottom trawlers) takes place between Burwood Bank and the shelf between the Falkland (Malvinas) Islands and Tierra del Fuego. Squid fishery is carried out in the shelf mainly between 100 $\mathrm{m}$ and $200 \mathrm{~m}$ isobaths (Fig. 4). The longline fishery, which targets species including the Patagonian toothfish and the pink cusk-eel, were expanded to new areas close to the slope (surroundings of Tierra del Fuego) and shelf in front of Santa Cruz Province and operate in sea bottoms avoided by trawlers (Fig. 5).

Incidental mortalities affect at least the southern sea lions and the dusky and Commerson's dolphins. Sea lions are caught in all fishing types while the delphinid species are mostly affected by the mid-water trawling for shrimp. The latter was widely used during the 1980s and seems now to be less used by the national fleet within the waters of the EEZ (Dans et al., 1998). However, mid-water trawling is still practised with unknown effects in the Patagonian grenadier and southern blue whiting 
fishery. Other operational interactions like damage to the catch or gear do not seem to be important in those fisheries.

With respect to trawling vessels, incidental mortalities differs in sea lions and dolphins, when the type of fishing vessels, catch rates and sex and age-classes caught are analysed. Sea lions seem to rank number one in bycaught marine mammals (Table 3). The number of animals caught range between $1-2 \%$ of the total population size of 30000 individuals estimated for the area (Reyes et al., 1996; Szapkievich and Crespo, 1992). Both species of dolphins seem to have smaller population size although based only on preliminary figures from pilot surveys (Schiavini et al., 1996).

Another fact to be considered when assessing the effects of by-catches on the marine mammal populations is which component of the population is mainly affected. The age structure of the sea lion catch in this study was biased towards subadult and probably adult males (which are thrown back to sea). In the case of dusky dolphins, the age structure of the catch was biased towards females of high reproductive value (Dans et al., 1993a, b, 1997). Half of the female sample were mature females and half of them are pregnant. The effects of such variations in mortalities between species can only be assessed by modelling excercises that are beyond the scope of this paper.

The sea lions overlap to a larger extent with the fishery as compared to the dolphins (Table 4) even though the species has a wider spectrum of food preferences. The hake, the most important target of the fishery, with higher levels of discard in the shrimp fishery, is preferred by sea lion males (Fig. 6, 7 and 10). Therefore, the hake and the shrimp fishery would be interacting more with sea lion males than with females. Females feed on a wider spectrum of preys than do males, some of which (like "raneya") are not of commercial values and are not discarded by the fishery.

Regarding the interaction between the squid fishery and sea lion females, it must be considered that females are more coastal than males (Crespo, 1988 ) and that the fishing area of the jigging vessels is between 100 and $200 \mathrm{~m}$ isobaths (Fig. 4). Therefore, competitive effects would only be tested under overfishing conditions of squid populations.
It should be noted that new catch regulations were established in 1994. The opportunistic feeding pattern of the species and particularly of the female section of the population tends to protect the sea lion of overfishing effects. However, incidental mortality and competitive effects together, would have limited for some time the recovery of the sea lion population since the development of the fisheries in the early-1970s after the depletion that occured between 1930s and 1950s (Crespo and Pedraza, 1991). In present days the population is showing signals of recovery with a rate of increase close to 3\% (Dans et al., 1996).

Situations of fast development of fisheries have been recorded previously in other parts of the world like the North Pacific after the Second World War. The intensive fishing in the area is considered to be a cause of decrease in population levels of Steller sea lions (Eumetopias jubatus) and northern fur seal (Callorhynus ursinus), both due to incidental mortalities and reduction of stocks of preys (Fowler, 1982; Loughlin and Nelson, 1986; Alverson, 1992).

The hake is the most important prey for the Commerson's dolphin eating small sizes neither captured nor discarded by the fishery (Fig. 6, 7 and $10)$. The same situation is observed in dusky dolphins which feed mainly on anchovies (Fig. 6 and 10). The second most important prey for both species of dolphins is the shortfin squid, smaller size than commercial value (Fig. 7,8 and 10).

Therefore, dolphins seem to be less affected than sea lions in the use of food resources, while they seem to be more susceptible to competitive effects. Dolphins have more restricted food preferences which suggest prey selection. It must be noted that most dolphins were collected during shrimp fishing operations although no shrimp was found in their stomach and that anchovy is a shrimp-associated species. Anchovy is usually not collected in the shrimp nets, leading to the conclusion that the fishing for shrimp has beneficial effects on the anchovy and indirectly on the dolphins and other species which feed on them.

It must be mentioned that other feeding studies carried out in Commerson's dolphins at the extreme south of South America were completely different, in which crustaceans, sardines and silversides were the most important food items (Bastida et al., 1988). 
TABLE 4. Adjusted general overlaps (GOa) between marine mammals and the samples from the shrimp fishery, $\mathrm{V}$ statistics and their statistical significations.

\begin{tabular}{lrrrr}
\hline \hline & Sea lion Male & Sea lion Female & Dusky dolphin & Commerson's dolphin \\
\hline Coastal Sample & & & & \\
GOa & 0.913 & 0.504 & 0.614 & 0.151 \\
V & 40.63 & 254.23 & 603.66 & 6 \\
df & 6 & 6 & $<0.05$ & 6 \\
p & $<0.05$ & $<0.05$ & & $<0.05$ \\
Offshore Sample & & & 0.126 & \\
GOa & 0.480 & 0.389 & 4060.94 & 0.042 \\
V & 559.87 & 648.31 & 6 & 4850.64 \\
df & 6 & 6 & $<0.05$ & 6 \\
p & $<0.05$ & $<0.05$ & & $<0.05$ \\
\hline
\end{tabular}

Regarding ecological interactions, particularly the use of common resources, even though an overlap between the marine mammals analysed and the fisheries exists, such overlap is not considered to generate strong competitive effects between them. However, a retrospective analysis of such interactions is impracticable today due to a lack of data and requires sophisticated modelling work.

\section{Acknowledgements}

The authors are indebted to the many people and institutions for collaborating in this research. We thank Centro Nacional Patagónico (Nat. Res. Council of Argentina), the University of Patagonia (CIUNPAT Research Projects $\mathrm{N}^{\circ} 143$ and 195), Fundación Patagonia Natural (Patagonian Coastal Zone Management Plan) and Whale and Dolphin Conservation Society for the institutional, logistical and financial support given throughout this study. We also wish to thank fisheries officers, officers of the Fishery Government Agencies of Chubut and Santa Cruz Province and the National Coast Guard. Finaly we thank R. González (Inst. Alte. Storni), Drs P. Gandini and E. Frere for their support and unpublished information. We also thank Dr J. Sigurjonsson and two anonymous reviewers for their useful suggestions about the manuscript.

\section{References}

ALVERSON, D.L. 1992. A review of the commercial fisheries and the Steller sea lion (Eumetopias jubatus): the conflict arena. Rev. Aquat. Sci., 6: 203-256.
ANGELESCU, V. 1982. Ecología trófica de la anchoíta del mar argentino (Engraulidae, Engraulis anchoita). Parte II. Alimentación, comportamiento y relaciones tróficas en el ecosistema. Serie Contribuciones $\mathrm{N}^{\circ} 409$, INIDEP. $83 \mathrm{p}$.

ANGELESCU, V. and L.B. PRENSKI. 1987. Ecología trófica de la merluza común del mar argentino (Merlucciidae, Merluccius hubbsi). Parte 2: Dinámica de la alimentación analizada sobre la base de las condiciones ambientales, la estructura y las evaluaciones de los efectivos en su área de distribución. Serie Contribuciones Nº561, INIDEP. $205 \mathrm{p}$.

ANON. 1994. Masiva presencia de furtivos en aguas argentinas. Redes de la Industria Pesquera Argentina, 8(75): 26-27.

BASTIDA, R. and V. LICHTSCHEIN. 1986. Capturas incidentales de pequeños cetáceos en el área de Mar del Plata (Provincia de Buenos Aires, Argentina). Prim. Reun. Exp. Mam. Acuát. Amér.Sur., 25-29 June 1984, Buenos Aires. [Actas]. 14-22.

BASTIDA, R., V. LICHTSCHEIN and R.N.P. GOODALL. 1988. Food habits of Cephalorhynchus commersonii off Tierra del Fuego. In: Biology of the genus Cephalorhynchus. R. L. Brownell and G. P. Donovan, (eds.). Rep. Int. Whal. Comm., Special Issue 9: 143-160.

BORREL, A., A. AGUILAR, J. CORCUERA and F. MONZÓN. 1990. Distribution of organochlorines in tissues and organs of the franciscana (Pontoporia blainvillei). Eur. Res. Cetacean [Abstracts], 4: 43.

BROWNELL, R. L. and R. PRADERI. MS 1974. Present research and conservation problems with the franciscana (Pontoporia blainvillei) in Uruguayan waters. Ad-hoc Group 2 Consult. Small Cet. Siren. ACMRR Working Party on Mar. Mam. FAO. 16-19 Dec. La Jolla. Calif., 16 p. 
CASTLEY, J. G., V. G. COCKCROFT and G. I. H. KERLEY. 1991. A note on the stomach contents of fur seals Arctocephalus pusillus beached on the south-east coast of South Africa. S. Afr. J. Mar. Sci., 11: 573577.

CLARKE, M. R. (ed.). 1986. A handbook for the identification of cephalopod beaks. Clarendon Press, Oxford. $273 \mathrm{p}$.

CORCUERA, J. and F. MONZÓN. 1990. Reproducción en hembras del delfín franciscana Pontoporia blainvillei en Necochea (Argentina). IV Reun. Esp. Mam. Acuát. Amér. Sur. [Abstracts]: 20.

CORCUERA, J., F. MONZÓN, E.A. CRESPO, A. AGUILAR and J.A. RAGA. 1994. Interactions between marine mammals and coastal fisheries of Necochea and Claromecó (Buenos Aires Province, Argentina). In: 1994 Gillnets and cetaceans. W. F. Perrin, G. P. Donovan and J. Barlow (eds.). Rep. Int. Whal. Comm., Special Issue 15: 283-290.

CRESPO, E. A. 1988. Dinámica poblacional del lobo marino del sur Otaria flavescens (Shaw, 1800), en el norte del litoral patagónico. Doc. Thesis, Facultad de Ciencias Exactas y Naturales, Universidad de Buenos Aires, 298 p.

CRESPO, E. A. and S.N. PEDRAZA. 1991. Estado actual y tendencia de la población de lobos marinos de un pelo (Otaria flavescens) en el litoral patagónico. Ecología Austral, 1: 87-95.

CRESPO, E. A., G. PÉREZ MACRI and R. PRADERI. 1986. Estado actual de la población de franciscana (Pontoporia blainvillei) en las costas uruguayas. Prim. Reun. Esp. Mam. Acuát. Amér. Sur., 25-29 June 1984, Buenos Aires. [Actas]. 92-105.

CRESPO, E. A., J. CORCUERA and A. LOPEZ CAZORLA. 1994a. Interactions between marine mammals and fisheries in some coastal fishing areas of Argentina. In: Gillnets and Cetaceans. W. F. Perrin, G. P. Donovan and J. Barlow, (eds.). Rep. Int. Whal. Comm., Special Issue 15: 269-281.

CRESPO, E. A., L. M. REYES, M. KOEN and N. GARCÍA. 1994b. Interacciones entre mamíferos marinos y pesquerías en el litoral Norpatagónico. In: IV Reun. Esp. Mam. Acuát. Amér. Sur., 12-15 November 1990. J. A. Oporto, (ed.).Valdivia. 89-96.

CRESPO, E. A., P. NEPOMNASCHY, M. KOEN ALONSO and N. GARCÍA. 1994c. Análisis preliminar de la dieta de mamíferos marinos sobre la base de contenidos estomacales y heces. In: $I V$ Reun. Esp. Mam. Acuát. Amér. Sur., 12-15 November 1990. J. A. Oporto, (ed.). Valdivia. p. 57-88.

CRESPO, E. A, A. C. M. SCHIAVINI, G. PÉREZ MACRI, L. REYES and S. DANS. 1994d. Estudios sobre determinación de edad en mamíferos marinos del Atlántico Sudoocidental. In: IV Reun. Esp. Mam. Acuát. Amér. Sur., 12-15 November 1990. J.A. Oporto, (ed.). Valdivia. p. 31-55.

DANS, S., E. A. CRESPO, M. KOEN ALONSO, L. M.
REYES and N. GARCÍA. 1993a. Biología y ecología del delfín oscuro Lagenorhynchus obscurus en el litoral patagónico. Aspectos preliminares. In: Actas de las Jorn. Nac. Cs del Mar "91", 15-21 September 1991. Puerto Madryn, p. 142-148.

DANS, S., S. PEDRAZA, M. KOEN ALONSO and E. A. CRESPO. 1993b. Aspectos preliminares de la biología reproduciva en hembras de delfín oscuro (Lagenorhynchus obscurus) del litoral norpatagónico. XVI Reun. Arg. Ecol. 19-22 April 1993, Puerto Madryn. [Abstracts]. $150 \mathrm{p}$.

DANS, S. L., E. A. CRESPO, S. N. PEDRAZA, R. Y. GONZALEZ and N. A. GARCIA. 1996. Estructura y tendencia de los apostaderos de lobos marinos de un pelo (Otaria flavescens) en el norte de Patagonia. Tech. Rep. of the Plan de Manejo Integrado de la Zona Costera Patagónica (Puerto Madryn, Argentina), No 13: 1-17.

DANS, S. L., E. A. CRESPO, S. N. PEDRAZA and M. KOEN ALONSO. 1997. Notes on the reproductive biology of female dusky dolphins (Lagenorhynchus obscurus) off Patagonian coast. Mar. Mam. Sci., 13(2): 303-307.

DANS, S. L., E. A. CRESPO, N. A. GARCIA, L. M. REYES, S. N. PEDRAZA and M. K. ALONSO. 1998. Incidental mortality of Patagonian dusky dolphins in mid-water trawling: retrospective effects from the early 1980s. Rep. Int. Whal. Comm., 47: 699-704.

FOWLER, C. W. 1982. Interactions of northern fur seals and commercial fisheries. Transactions of the 47 th North American Wildlife and Natural Resources Conference. The wildlife Management Institute. Washington DC., p. 278-292.

GEORGE NASCIMENTO, M. F., R. A. BUSTAMANTE and R. C. OYARZUN. 1985. Feeding ecology of the southern sea lion Otaria flavescens Shaw, 1800: Food contents and food electivity. Mar. Biol.-Prog,. Series, 21: 135-143.

GOODALL, R. N. P., A. C. M. SCHIAVINI and C. FERMANI. 1994. Net fisheries and net mortality of small cetaceans off Tierra del Fuego, Argentina. In: Gillnets and Cetaceans. W. F. Perrin, G. P. Donovan and J. Barlow, (eds.). Rep. Int. Whal. Comm., Special Issue 15: 295-306.

HOHN, A. A. 1980. Age determination and age related factors in the teeth of Western North Atlantic bottlenosed dolphins. Sci. Rep. Whales Res. Inst., Tokio, 32: 39-66.

HOHN, A. A., S. J. CHIVERS and J. BARLOW. 1985. Reproductive maturity and seasonality of male spotted dolphins, Stenella attenuata, in the Eastern Tropical Pacific. Mar. Mam. Sci., 1(4): 273-293.

KASUYA, T. and R. L. BROWNELL. 1979. Age determination, reproduction and growth of the franciscana dolphin, Pontoporia blainvillei. Sci. Rep. Whales Res. Inst., Tokio, 31: 45-67. 
KOEN ALONSO, M., E. A. CRESPO and S. N. PEDRAZA. 1993a. Análisis de contenidos estomacales del lobo marino de un pelo, Otaria flavescens, en el norte de Patagonia. Jorn. Nac. Cs. Mar "93". 19-25 September 1993, Puerto Madryn. [Abstracts]. $151 \mathrm{p}$.

KOEN ALONSO, M., S. N. PEDRAZA, E. A. CRESPO and N. GARCÍA. 1993b. Análisis de la dieta y diversidad trófica del delfín oscuro (Lagenorhynchus obscurus) en el litoral norpatagónico. XVI Reun. Arg. Ecol., 19-22 April 1993, Puerto Madryn. [Abstracts]. $180 \mathrm{p}$.

KOEN ALONSO, M., E. A. CRESPO, N. A. GARCÍA, S. N. PEDRAZA and M. COSCARELLA. 1998. Diet of dusky dolphins, Lagenorhynchus obscurus, in waters of Patagonia, Argentina. Fish. Bull., 96: 366-374.

LOUGHLIN, T. R. and R. NELSON. 1986. Incidental mortality of northern sea lions in Shelikof Strait, Alaska. Mar. Mam. Sci., 2(1): 14-33.

LUDWIG, J.A. and J.F. REYNOLDS. 1988. Statistical ecology. John Wiley \& Sons, New York. 335 p.

MONZÓN, F. and J. CORCUERA. 1990. Análisis preliminar de madurez sexual en machos de delfín franciscana (Necochea, Provincia de Buenos Aires, Argentina). IV Reun. Esp. Mam. Acuát. Amér. Sur. 12-15 November 1990. Valdivia. [Abstracts]. 46 p.

NORRIS, K. S. 1961. Standarized methods for measuring and recording data on the smaller cetaceans. J. Mammal., 42(4): 471-476.

PÉREZ MACRI, G. P. 1986. Estudios de alimentación y mortalidad en redes de pesca del delfín franciscana Pontoporia blainvillei (Cetacea: Platanistidae) en el área de Bahía Samborombón. Informe interno Comisión de Investigaciones Científicas de la Pcia. de Buenos Aires (CIC), 47 p.

PÉREZ MACRI, G. and E.A. CRESPO. 1989. Survey of the franciscana, Pontoporia blanvillei, along the Argentine coast, with a preliminary evaluation of mortality in coastal fisheries. Occas. Pap. IUCN $S S C$, 3: 57-63.

PERRIN, W. F. and G. P. DONOVAN. 1984. Report of the Workshop. In: Reproduction in Whales, Dolphins and Porpoises. W. F. Perrin, R. L. Brownell and D. P. DeMaster, (eds.). Rep. Int. Whal. Comm., Special Issue 6: 1-24.

PERRIN, W.F. and A.C. MYRICK, Jr. 1980. Report of the workshop. In: Age determination of toothed whales and sirenians. W. F. Perrin and A. C. Myrick, Jr., (eds.). Rep. Int. Whal. Comm., Special Issue 3: $1-50$.

PETRAITIS, P. S. 1979. Likelihood measures of niche breadth and overlap. Ecology, 60(4): 703-710.

PINEDO, M. C. MS 1982. Análise dos contéudos estomacais de Pontoporia blainvillei (Gervais and D'Orbigny, 1984) e Tursiops gephyreus (Lahille, 1908) (Cetacea, Platanistidae e Delphinidae) na zona estuarial de Rio Grande, R. S. Brasil. Masters Thesis, Fundação Universidae do Rio Grande, RS,
Brazil. 95 p.

1985. Intentional and incidental capture of marine mammals in fishing nets. Prim. Reun. Exp. Mam. Acuát. Amér. Sur., 25-29 June 1984, Buenos Aires. [Conclusiones]. p. 76-80.

1986. Mortalidade de Pontoporia blainvillei, Tursiops gephyreus, Otaria flavescens e Arctocephalus australis na costa do Rio Grande do Sul, Brasil, 1976-1983. Prim. Reun. Exp. Mam. Acuát. Amér. Sur., 25-29 June 1984, Buenos Aires. [Actas]. p. 187-199.

PINKAS, L., M. S. OLIPHANT and I. L. K. IVERSON. 1971. Food habits of albacore, bluefin tuna and bonito in California waters. Fish. Bull. U. S., 152: $1-105$.

PRADERI, R. MS 1976. Incidental catch of franciscana, Pontoporia blainvillei, in shark gillnets off Uruguay, 1975. Working Paper L28 presented to the IWC SubCommittee on Small Cetaceans, London, June 1976, $13 \mathrm{p}$.

MS 1979. Considerations on the population of franciscana, Pontoporia blainvillei, and its modifications due to commercial fishing in Uruguayan waters. Working Paper SC/31/SM4 presented to the IWC Scientific Sub-Committee on Small Cetaceans, Cambridge, June 1979. 13 p.

MS 1982. Research and conservation on dolphins incidentally caught in Uruguay. II. Nat. Geog. Soc. Grant 2404-81, 15 July 1982.

MS 1983. Incidental mortality of dolphins in Uruguay. Nat. Geog. Soc. Grant. 2558-82, 30 July 1983. 57 p.

PRADERI, R., M. C. PINEDO and E. A. CRESPO. 1989. Conservation and management of Pontoporia blainville $i$ in Uruguay, Brazil and Argentina. Ocass. IUCN SSC, 3: 52-56.

RAGA, J. A., J. A. BALBUENA and J. AZNAR. 1990. Preliminary data on the parasite fauna of the franciscana in Argentinean waters. Eur. Res. Cetacean [Abstracts], 4: 119-120.

REYES, L.M., E.A. CRESPO, and J.A. RAGA. 1992. Estudio preliminar de los endoparásitos gastrointestinales de mamíferos marinos de Patagonia en relación a su modo de vida. V Reun. Esp. Mam. Acuát. Amér. Sur. 28 September-2 October 1992. Buenos Aires. [Abstracts]. 55 p.

REYES, L. M., E. A. CRESPO, M. KOEN ALONSO and J. A. RAGA. 1993. Relaciones entre parásitos, presas y modo de vida de mamíferos marinos patagónicos. XVI Reun. Arg. Ecol. 19-22 April 1993, Puerto Madryn. [Abstracts]. 104 p.

REYES, L. M., E. A. CRESPO, Y. V. SZAPKIEVICH. 1996. Distribución y abundancia de lobos marinos de un pelo (Otariaflavescens) en el centro y sur de Chubut, Argentina. Tech. Rep. of Plan de Manejo Integrado de la Zona Costera Patagónica (Puerto Madryn, Argentina) $\mathrm{N}^{\circ}$ 10: p. 1-22.

SCHIAVINI, A. C. M., S. N. PEDRAZA, E. A. CRESPO, 
R. GONZALEZ and S. L.DANS. 1996. The abundance of dusky dolphins (Lagenorhynchus obscurus) off central patagonia, Argentina. Results from a pilot survey in spring 1995. Working Paper presented to the IWC Scientific Sub-Committee on Small Cetaceans, Aberdeen, Scotland, June 1996. 16 p.
SZAPKIEVICH, V. and E.A. CRESPO 1992. Estimación de la población de Otaria flavescens (Shaw, 1800) en el litoral patagónico mediante fotografías obtenidas en censos aéreos. V Reun. Esp. Mam. Acuát. Amér. Sur., 28 September-2 October 1992, Buenos Aires. [Abstracts]. 67 p. 